\title{
The Formation and Evolution of Interorganisational Business Networks in Megaprojects: A Case Study of Chinese Skyscrapers
}

\author{
Yujie Lu $\mathbb{D}^{1,2,3}$ Wei Wei, ${ }^{1}$ Yongkui Li, ${ }^{4}$ Zhilei Wu $\mathbb{D},{ }^{4}$ and Hao Jin ${ }^{5}$ \\ ${ }^{1}$ Department of Building Engineering, College of Civil Engineering, Tongji University, Shanghai 200092, China \\ ${ }^{2}$ Key Laboratory of Performance Evolution and Control for Engineering Structures of Ministry of Education, Tongji University, \\ Shanghai 200092, China \\ ${ }^{3}$ Shanghai Institute of Intelligent Science and Technology, Tongji University, Shanghai 200092, China \\ ${ }^{4}$ Department of Construction Management and Real Estate, School of Economics and Management, Tongji University, \\ Shanghai 200092, China \\ ${ }^{5}$ School of Public Economics and Administration, Shanghai University of Finance and Economics, Shanghai 200433, China
}

Correspondence should be addressed to Zhilei Wu; w.zl2@163.com

Received 16 July 2020; Revised 23 September 2020; Accepted 30 September 2020; Published 21 November 2020

Academic Editor: Guangdong Wu

Copyright ( 2020 Yujie Lu et al. This is an open access article distributed under the Creative Commons Attribution License, which permits unrestricted use, distribution, and reproduction in any medium, provided the original work is properly cited.

\begin{abstract}
Megaprojects are implemented by different organisations, such as owners, consultants, and contractors. Gradually, these organisations and their connections can form business networks that influence both the market position of individual organisations and project performance. Previous research on large-scale projects mainly focused on static and homogeneous networks that were constructed by one individual project and/or carried out over one-off collaboration. However, this neglected the consideration of project network diversity, as well as repetitive, dynamic, cross-project coopetition relationship (i.e., collaboration and competition) and long-term business networks formed by key actors. Here, we chose Chinese skyscrapers over 300 meters that were built from 1996 to 2015 as typical megaproject cases and analysed the formation and evolution of megaproject business networks from the perspective of interorganisational coopetition. We identified the key actors involved and empirically studied their dynamic network positions over time. The main contributions of this study are threefold. First, we found that past collaboration experience has direct and dynamic impacts on the formation of megaproject business networks. Second, we identified key actors in the interorganisational business network and unveiled their dynamic positions with clear patterns. Third, we highlighted the temporal-spatial effect on the formation and development of business networks, alongside developments in the megaproject market. The findings of this study also provide practical applications for owners to choose collaboration partners and to build high-performance teams and for suppliers to enter and sustain the business in the megaprojects networks.
\end{abstract}

\section{Introduction}

In the fields of architecture, engineering, and construction (AEC), companies tend to work on project-based businesses. The short-term nature of AEC projects can result in shortterm collaborative relationships and market competitionoriented long-term business networks (also referred to "coopetition"). Artto and Kujala classified the research of AEC projects into four aspects: (1) management of a project; (2) management of a project-based organisation; (3) management of a project network; and (4) management of a business network [1]. Among those, the feature of business networks is the most complex and has become an emerging research area which involves multiple projects and organisations. It includes a temporary network and a permanent network, and the two can coexist and interact with each other. Business networks are dynamic and subject to the influences of temporal, spatial, and contextual factors. Törnroos applied the IMP business network approach, introducing the concept of space, and demonstrated its central role in describing the change and emergence of networks [2].

Megaproject is a booming field in the AEC industry, and it refers to large-scale engineering projects such as bridges, tunnels, and public buildings that require investment of 
more than one billion US dollars [3] and requires longer than one political dispensation for constructive construction [4]. As typical representatives of large-scale megaprojects, skyscrapers are super high-rise buildings with a height of more than $300 \mathrm{~m}$. This has created a new area in project management theoretical studies. Megaprojects are largescale in construction, finance, and management and therefore require a large workforce. In this study, companies involved in megaprojects are defined as "complex network of actors." The experience and levels of synergy between these actors impact a megaproject's performance greatly. Owners working on megaprojects should therefore select the appropriate suppliers (such as designers and contractors) to form high-performing and effective teams. This can help them avoid overinvestments and financial overruns that commonly occur. Suppliers, on the other hand, should find ways to enter the market, build, and maintain their business networks to retain their market competitiveness. However, there first needs to be an understanding of how business networks form and continually evolve in megaprojects.

Research areas on project networks, business networks, industrial marketing, and purchasing networks have relatively rich literature. Artto and Kujala have initially classified the research themes and fields on "management of a business network" in project business [1]. To highlight a few, these include the relationship between temporary project networks and permanent business networks, performance measurements in business networks, analysis of networked business environments, the design of an organisation's strategy, and the ever-changing roles of a network's players.

But their research mainly focused on the introduction of the theoretical framework, focusing on how to effectively manage companies and projects in the existing network business environment, and did not introduce how the business network is formed and evolved. To enrich the research on the project network, we conduct case studies of Chinese skyscrapers based on the "Management of a project network" and "Management of a business network" sections of the framework outlined by Artto and Kujala [1] and use social network analysis to study the formation process and evolution characteristics of business networks between organisations in specific megaproject areas. In order to study this issue, we first identified key players with different attributes in the business network and analysed the relationships and evolutionary characteristics between the participants. At the same time, it also explored the influence of geographical factors on the formation and evolution of business networks in the field of megaprojects.

We first reviewed and presented the related theoretical background, current research status, and future research trends of interorganisational megaproject business networks. Following this, we explained our research methods, which include framework design, data collection, and analysis methods. We then analysed and discussed the calculated results of each parameter. Finally, we concluded the practical and theoretical implications of this research and the limitations leading to future research developments.

\section{Theoretical Background}

According to Industrial Marketing and Purchasing (IMP), organisations must build long-term and collaborative relationships to occupy the market, make profit, and sustain themselves [5]. Those relationships are diverse. Gummesson classified them into four types: classic market relationships, special market relationships, mega relationships, and nano relationships [6]. The first two types are relationships between suppliers, customers, competitors, and others who operate the market; this forms market relationships. The latter two types are nonmarket relationships, which influence the efficiency of market relationships indirectly. The ability of an organisation to develop and manage its relationships with other organisations successfully is viewed as a core competency in a business and as a fundamental property of any living organism and an important component of social capital.

Business networks are formed when organisation-toorganisation relationships are created, developed, and maintained. A business network can be defined as a set of two or more connected business relationships, where each exchange relationship lies between business organisations that are conceptualized as collective actors. The dynamic capabilities of an organisation are defined by Zollo and Winter as the activities directed to the development and adaptation of operating routines from the coevolution of three roles: experience accumulation, knowledge articulation, and knowledge codification [7]. Due to the complexity of the AEC industry, business networks in a particular sector are generally large and complex-hundreds of actors constitute thousands of relationships. The capabilities of each actor in the network, the closeness of their relationships, and the efficiency of collaboration play a huge role in achieving project goals. The influence can be even more obvious in situations where complex tasks or projects cannot be accomplished by single organisations. Hence, repeated collaborative firms with interorganisational experiences could result in knowledge accumulation in a project alliance, create new growth opportunities, and enable partnering firms to achieve their strategic objectives [8].

Business networks are dynamic over a longer period of time. This is due to the addition of new actors and the establishment of constant new relationships in mutual competitive relationships. Cooperation relationship is the trade-off between collaboration and competition among participants, and it is a means for participants to create progress in long-term relationships [9]. Therefore, time is an important factor to understand the evolution of the business relationship and network. Over time, almost all other elements are in active or passive change and adapting dynamically within networks. The location of different actors in networks, for example, indicates their different resources, thus influenced by the embeddedness phenomenon [10]. Actors in evolving networks face the pressure to maintain a favourable network position [11]. New actors compete with existing actors. Relationships between actors change due to the pressure of competition and their past experience of working together. Since the market is open and dynamic, 
spatial, and environmental, contextual factors have a significant impact on the formation and evolution of networks.

In the AEC industry, interorganisational project teams are set up to accomplish project goals. The ability of project participants to form a high-performance team is one of two fundamental elements to successful project delivery [12]. The selection of effective partnership therefore becomes a key step in achieving high-performance outputs, as repeated collaboration practices among team members are likely to result in shared objectives, working methods, and values. Organisations can better understand the reliability and capabilities of their partners if they have collaborated with them in the past. Moreover, teams are commonly formed based on past collaboration experience for better commitment and trust $[13,14]$. Over time, these members are able to foster a close-working relationship, reinforced also by working in close locations. Interorganisational relationships between project network actors which are developed over the course of multiple projects may also lead to opportunities for learning, reduced supervisory costs, and a reduced risk of project failure [15].

Short-term relationships and strategic collaborative long-term relationships form gradually between actors during project collaborations. Compared to short-term relationships, long-term relationships are more crucial for individual organisation in a long run. According to the theory of Industrial Network Approach (INA), long-term relationships and adaptations are key sources of added values because they help expedite the learning curve in new projects, therefore facilitating higher return on investments [13]. Organisations taking up short-term projects instead focus on the goal of achieving longer-term partnerships, due to the increased incentives for better collaboration [16]. However, uniqueness of the product, the short-term setup of project teams, the competitive bidding process, the customized but standard contract, and cultural differences could all impede the establishment of long-term relationships. For example, clients may worry their long-time collaborated contractors become too "cozy" and uncompetitive [16]. Relationships are not easy to maintain, due to the Discontinuity-Uniqueness-Complexity feature that distinguishes project-based marketing from the business-tobusiness marketing [17].

The complex temporal and long-term relationship in the AEC industry creates unique project networks and business networks or first-tier and second-tier networks [18]. A construction project can be viewed as a network of relationships between organisations, thus forming project teams; this is essentially a network of interorganisational relationships $[19,20]$. It is also appropriate to consider a project as a temporary network within a permanent network [16]. A successful project delivery requires integrated components, skills, and knowledge from each organisation to manage and solve complex tasks. It therefore depends on actors within the temporary project network (e.g., engineering teams, financing systems, and investors) and how they coordinate work among themselves [16, 21, 22]. Longterm networks, or business networks, are formed after several collaborations. It is also called interorganisational networks [23] or the second-tier network. As shown in Figure 1, actors $\mathrm{O} 1, \mathrm{O} 2, \mathrm{O} 3$, and $\mathrm{O} 4$ may form a permanent network after three projects and build the interorganisational collaborations, P1, P2, and P3. Artto and Wikström defined it as "Project business is the part of business that relates directly or indirectly to projects, with the purpose of achieving objectives of an organisation or several organisations" [24]. This definition refers to multiple projects and multiple organisations.

Artto and Kujala stated that the management of a business network includes novel research themes that relate to several organisations' activities, where the organisations engage from time to time in mutual projects [1]. The actors in the business network can have aims that overlap and provide opportunities for partnership and collaboration $[25,26]$. As for project clients, the aim of a temporary project network is to achieve collective network capability. This consists of the combination of contributed capabilities of network actors and defines the strength or effectiveness of the network to achieve its business aims [27, 28]. For other actors, their network locations are also critical. In fact, each node's location determines an organisation's ability to access external information and resources [29] and is also referred to as an important concept of "social structure." This can enhance an organisation's ability to create new value and achieve economic goals, such as winning procurement projects, for instance [15], and is also a representation of high social capitals [30]. Therefore, long-term collaborationbased business networks have a critical influence on the survival and development of organisations from a project marketing perspective. Organisations need to keep looking for partners to build relationships, form collaborative networks, or enter a specific network, and then gradually occupy a certain network location to achieve a higher social capital.

The study of megaprojects has become a hot topic in theory and practice in recent years, but has been widely critiqued for their poor research findings. More research studies on theoretical studies are needed to address the "tension phenomenon" between theories and practices [31]. Megaprojects are not only more challenging than traditional AEC projects, but also take a longer time to deliver and have strong uncertainties. They therefore require more social resources. The organisational relationships of megaprojects are made out of complex networks [19, 28, 32, 33], but there has been a lack of research in this area as most studies focused only on individual project networks or theoretical frameworks $[28,32]$. One research study investigated how second-tier networks were formed in initial phases, while Lu et al. researched on a revolution issue in regional megaprojects [34]. Thus, there is a need for more in-depth research on cross-organisational collaborations and business networks in megaprojects to understand how business networks are built and have evolved. To investigate the formation of interorganisational collaboration and business networks and how relationships between these actors change in the megaprojects field, we chose Chinese skyscrapers over 300 meters that were built in 1996-2015 as case studies in this research. 


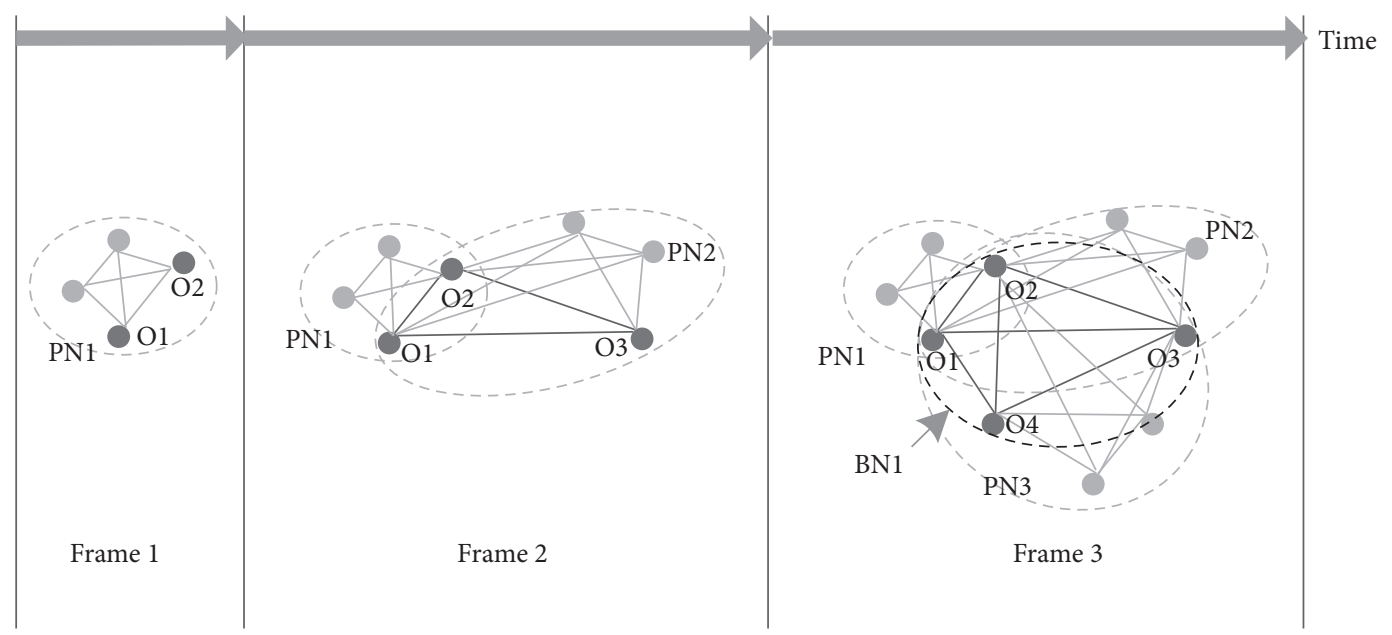

FIGURE 1: Formation process of project-based interorganisational collaboration business network. O represents organisation or participant, $\mathrm{PN}$ represents project network, and BN represents business network.

\section{Method}

3.1. Research Scope and Development. Interorganisational collaborations and business relationships are getting more complicated as the project and market become more complex and larger-scaled. As a result, the network features of such project networks become more representative. Skyscrapers are clearly typical complex and large-scale projects that involve many organisations and vast financial investments. Therefore, we chose skyscraper projects to represent complex megaprojects in this study to analyse the characteristics of interorganisational collaboration and business networks.

We firstly created a skyscraper dataset that catalogued all built skyscrapers over 300 meters in China. For each skyscraper project, project attributes (e.g., height, geographical location, and start and complete time), core project organisations (e.g., project client or investor, design company, general contractor, specialty subcontractor, and engineering supervisor), and organisational attributes (e.g., headquarter location and ownership property) were recorded. Different network models were then built based on the dataset. We used the completion date of individual skyscraper projects as the longitudinal time stamp to indicate the different formation stages of the network, and the dynamic changes of the whole network and individual networks were modelled and calculated.

There are multiple analysis methods in the process of network dynamic changes, such as computer simulation, and social network analysis (SNA). SNA is a method for studying the exchange of resources between participants (i.e., individuals, groups, or organisations). It can be applied to the field of architecture to perform network analysis between organisations [35]. The research focus of this approach is on communication issues between key people in the project network within the organisation [36] such as clients, supervisors, designers, and construction managers. The research object of this method is consistent with the key stakeholders in this study, and the key parameters of this method can be used to reflect the interaction between participants.
Social network analysis mainly uses the following metrics to quantify the relationship between participants: (i) the contractual relationship between project participants; (ii) the frequency with which project participants execute tasks closely related to achieving project goals; and (iii) the frequency with which participants perform similar types of works in the organisation. In this study, the characteristics of the formation and evolution of business networks were discussed, which are based on the exchanges and collaboration between participants. Metric (ii) has been selected in this study because it can measure the frequency of participants' engagement with one another in achieving common project goals in the business network, so as to better analyse the level of collaboration among participants and the formation process of the project network [37].

Therefore, this research constructed a social network based on metric II and applied the SNA method to analyse the dynamic changes of the network and examined the network density, network concentration, and the centralisation index within the whole network. However, degree centrality and the betweenness centrality of key stakeholders (including designers, contractors, and quality supervisors) were examined in individual networks.

Based on the SNA results and calculated key parameters, we analysed the formation and evolution of interorganisational collaboration and business network of skyscrapers over 300 meters in China, studied the positions and position changes of main organisations within the network, and evaluated how organisational properties and geographical locations influenced the business networks.

3.2. Data Collection and Coding. We ensured that the data used were authentic and accurate so as to provide a throughout checking on organisational networks. We sourced our data from the Skyscraper Centre of the Council on Tall Buildings and Urban Habitat (CTBUH) and the Mega Projects Case Study and Data Centre (MPCSC) database developed by the Research Institute of Complex 
Engineering \& Management (RICEM), from Tongji University, China. CTBUH is a world's leading agency, specialising in the inception, design, construction, and operation of tall buildings and future cities (see http://www. ctbuh.org). The Council's free database on tall buildings-the Skyscraper Centre (see http://www. skyscrapercenter.com/) - is updated daily with detailed information, images, data, and news on global skyscrapers. MPCSC database includes Chinese engineering megaprojects spanning 12 categories such as skyscrapers, high-speed rails, and bridges, and more than 300 data cases. To further ensure data accuracy, each data point is verified by the official or published project documents to ensure that it meets rigorous requirements.

All Chinese building skyscrapers over 300 meters used the Design-Bid-Build (DBB) traditional delivery model. In this model, owners are responsible for procurement while designers and contractors are responsible for the design and construction of skyscrapers. Owners, designers, and contractors are the core teams in a megaproject. Due to the characteristics and complexities of skyscraper projects, project design teams responsible for architectural, structural, mechanical, and electrical designs are the key. General contractors and specialist subcontractors (e.g., curtain wall subcontractor, steel structure subcontractor, and mechanical and electrical subcontractors) follow the conventional construction procurement and are the core construction team that determines the success of a project delivery. It is worth noting that the number of participated organisations varies from project to project since the delivery methods and contracts differ for each case.

In China, the Diwang Tower of Shenzhen was the first recorded skyscraper that exceeded 300 meters. It was built in 1996, at 383.95 meters of height. As of December 31, 2015, China has built 43 skyscrapers that exceed 300 meters, as indicated in Table 1. According to China's SAIC query enterprise classification and registration information repository, 68 major design firms (including 24 state-owned at $36 \%, 6$ private-owned at $9 \%$, and 37 foreign-owned at $55 \%$ ), 40 major contractors (including 24 state-owned at $64 \%, 8$ private-owned at $21 \%$, and 6 foreign-owned at 15\%), 25 construction supervisory companies (including 13 stateowned at $52 \%$ and 12 private-owned at $48 \%$ ), and 54 clients or investors participated in the design and construction of skyscrapers over the last 20 years. There was a total of 13 years (except years 1998, 2001 through 2005, and 2007) in which at least one skyscraper was completed in construction, as tabulated in Table 2.

We coded the collected skyscraper projects and the participating organisations separately to analyse the information more effectively. There are five digits in the coding of the projects: the first two digits indicate the city of the project's location, the third digit represents the six geographical regions, including Southern, Eastern, Northern, Central, Southwest, and Northeast, while the last two digits stand for the sequences of the projects. For instance, Jinmao Tower is coded as 02303 , indicating that it is located in the city of Shanghai, Eastern China. Organisations are coded in eight digits. The first digit indicates the main role of an organisation, where $\mathrm{O}, \mathrm{D}, \mathrm{C}$, and $\mathrm{S}$ each stands for owner/ client, design firm, contractor, and supervisor, respectively; the second digit specifies the type of contractor, that is, general contractors or specialty contractors; digits three and four denote the city where the headquarter of the company is located; the fifth digit represents the type of ownership of organisations, including state-owned, private-owned, or foreign-owned; and the last three digits are the sequence number for an organisation. For example, Jangho Group, a curtain wall contractor, is coded as C4012083, indicating that it is a specialty contractor headquarters located in Beijing.

3.3. Analysis Methods. We analysed the characteristics of interorganisational networks using the parameters of whole networks and individual networks in SNA. For the analysis of whole networks, measures such as density, network centralisation, and centralisation index were used to measure the proportion of all possible ties present. These measures were also used to quantify the dispersion or variation among individual centralities and betweenness centralities and some other structural properties of whole networks. Degree centrality and betweenness centrality are discussed in individual networks, in order to quantify the number of connections an actor (node) has, the distance of an actor to all others in the network, and the extent to which an actor falls on the geodesic paths between other pairs of actors in the network [37-39]. The interpretation, calculation methods, and application of each measure are tabulated in Table 3.

Due to the characteristics of the supply chain in the AEC industry, geographical locations may not only influence project procurement, but also affect the formation, collaboration, and innovation in project teams. In order to quantify such geographical impacts, we introduced a location consistency indicator $C_{\mathrm{LPO}}$. The indicator measures a wide range of geographical consistencies, including the consistency between the location of a project and the location of a construction organisation, the consistency between the location of a corporate headquarter and the location of a project, and the consistency between the location of all projects and the location of all construction organisations in a network. The higher the value of a location consistency indicator, the greater the impact of a megaproject network caused by the location. The formula of the location consistency between the locations of project $i$ and the location of respective organisation $j$ (such as designers, contractors, and supervisors) is shown as follows:

$$
C_{\mathrm{LPO}}(j)=\frac{S_{j}^{\prime}}{S_{j}},
$$

where $S_{j}^{\prime}$ represents the number of the participating construction organisations which location is consistent with that of project $i$ and $S_{j}$ represents the total number of construction organisations in project $i$.

The formula for the location consistency between the locations of project $i$ and the location of all organisations, 
TABLE 1: General information of 43 skyscrapers above 300 meters.

\begin{tabular}{|c|c|c|c|c|c|c|}
\hline No. & Project name & $\begin{array}{l}\text { Height } \\
(\mathrm{m})\end{array}$ & Location & Client or investor & $\begin{array}{l}\text { Start } \\
\text { time }\end{array}$ & $\begin{array}{l}\text { Completion } \\
\text { time }\end{array}$ \\
\hline 1 & Shanghai Tower & 632 & Shanghai & $\begin{array}{c}\text { Shanghai Tower Construction \& } \\
\text { Development }\end{array}$ & 2008 & 2015 \\
\hline 2 & Ping An Finance Center & 599 & Shenzhen & $\begin{array}{c}\text { Ping An Life Insurance Company of } \\
\text { China }\end{array}$ & 2009 & 2015 \\
\hline 3 & Goldin Finance 117 & 596.5 & Tianjin & Goldin Properties Holdings Limited & 2009 & 2014 \\
\hline 4 & Guangzhou CTF Finance Centre & 530 & Guangzhou & Chow Tai Fook Enterprises & 2009 & 2014 \\
\hline 5 & Tianjin Chow Tai Fook Binhai Center & 530 & Tianjin & $\begin{array}{l}\text { Tianjin New World Huan Bo Hai Real } \\
\text { Estate Development Co. Ltd. }\end{array}$ & 2009 & 2014 \\
\hline 6 & Shanghai World Financial Center & 494.3 & Shanghai & $\begin{array}{l}\text { Shanghai World Financial Center Co., } \\
\text { Ltd. }\end{array}$ & 1997 & 2008 \\
\hline 7 & Zifeng Tower & 450 & Nanjing & $\begin{array}{c}\text { Greenland Group; Nanjing State-Owned } \\
\text { Assets }\end{array}$ & 2005 & 2009 \\
\hline 8 & Kingkey 100 & 441.8 & Shenzhen & $\begin{array}{l}\text { Shenzhen Kingkey Real Estate } \\
\text { Development Co. Ltd. }\end{array}$ & 2007 & 2011 \\
\hline 9 & $\begin{array}{c}\text { Guangzhou International Finance } \\
\text { Center }\end{array}$ & 437.5 & Guangzhou & Yue Xiu Group & 2005 & 2010 \\
\hline 10 & Jin Mao Building & 420.5 & Shanghai & China Jin Mao Group Co. Ltd. & 1994 & 1999 \\
\hline 11 & CITIC Plaza & 391.1 & Guangzhou & $\begin{array}{c}\text { China International Trust and } \\
\text { Investment }\end{array}$ & 1993 & 1997 \\
\hline 12 & Di Wang Commercial Centre & 383.9 & Shenzhen & Shun Hing Group & 1993 & 1996 \\
\hline 13 & Eton Place Dalian Tower 1 & 383.5 & Dalian & Eton Properties Limited & 2009 & 2014 \\
\hline 14 & Guangsheng International Building & 360 & Guangzhou & $\begin{array}{c}\text { Guangdong Sheng Ming Real Estate } \\
\text { Development Co., Ltd. }\end{array}$ & 2007 & 2012 \\
\hline 15 & SEG Plaza & 355.8 & Shenzhen & $\begin{array}{c}\text { Shenzhen SEG Plaza Investment } \\
\text { Development }\end{array}$ & 1997 & 2000 \\
\hline 16 & The Wharf Times Square & 339 & Wuxi & The (Wharf) Holdings Limited & 2010 & 2014 \\
\hline 17 & Chongqing World Financial Center & 338.9 & Chongqing & Chongqing Worthy Land Co., Ltd. & 2010 & 2014 \\
\hline 18 & Deji Plaza Phase 2 & 337.5 & Nanjing & $\begin{array}{l}\text { Nanjing Xinyu House Property } \\
\text { Development Co., Ltd. }\end{array}$ & 2009 & 2013 \\
\hline 19 & Tianjin World Financial Center & 336.9 & Tianjin & $\begin{array}{c}\text { Finance Street Tianjin Real Estate Co., } \\
\text { Ltd. }\end{array}$ & 2007 & 2011 \\
\hline 20 & Shimao International Plaza & 333.3 & Shanghai & Shimao Group & 2001 & 2006 \\
\hline 21 & Changzhou Modern Media Center & 333 & Changzhou & Changzhou Broadcasting Station & 2008 & 2013 \\
\hline 22 & Minsheng Bank Building & 331.3 & Wuhan & $\begin{array}{c}\text { Wuhan Xiangli Real Estate Development } \\
\text { Co., Ltd. }\end{array}$ & 2001 & 2006 \\
\hline 23 & China World Tower & 330 & Beijing & China World Trade Centre, Co., Ltd. & 2005 & 2009 \\
\hline 24 & Huaxi Tower & 328 & Wuxi & Village of Huaxi & 2007 & 2011 \\
\hline 25 & Wuxi Suning Plaza 1 & 328 & Wuxi & Suning Real Estate Group & 2009 & 2013 \\
\hline 26 & Fulton WorldTradeCenter1 & 328 & Nanjing & F\&T Group & 2011 & 2014 \\
\hline 27 & Yantai Shimao No. 1 The Harbour & 323 & Yantai & Shimao Group & 2007 & 2014 \\
\hline 28 & Wenzhou Trade Center & 321.9 & Wenzhou & $\begin{array}{c}\text { Wenzhou International Trade Real Estate } \\
\text { Development Co., Ltd. }\end{array}$ & 2005 & 2009 \\
\hline 29 & Global City Square & 318.9 & Guangzhou & KWG Property Holdings Limited & 2010 & 2014 \\
\hline 30 & $\begin{array}{c}\text { Nanjing International Youth Cultural } \\
\text { Centre Tower } 2\end{array}$ & 314.5 & Nanjing & $\begin{array}{l}\text { Nanjing Qingdao City Construction and } \\
\text { Development Co., Ltd. }\end{array}$ & 2009 & 2014 \\
\hline 31 & Maoye Center Tower 1 & 311 & Shenyang & Shenyang Maoye Real Estate Co., Ltd. & 2008 & 2014 \\
\hline 32 & Pearl River Tower & 309.7 & Guangzhou & $\begin{array}{c}\text { The Guangzhou Pearl River Tower } \\
\text { Properties }\end{array}$ & 2007 & 2011 \\
\hline 33 & Yuexiu Financial Mansion & 309.4 & Guangzhou & Yuexiu Real Estate Investment Trust & 2011 & 2014 \\
\hline 34 & Donghai International Center E & 308.6 & Shenzhen & Shenzhen Tianqi Real Estate Co., Ltd. & 2007 & 2013 \\
\hline 35 & $\begin{array}{l}\text { New World International Conference } \\
\text { and Exhibition Center } 1 \& 2\end{array}$ & 308 & Shenyang & Hong Kong New World Group & 2009 & 2013 \\
\hline 36 & Wuxi Maoye City Phase 2 & 303.8 & Wuxi & Shenzhen Maoye Group & 2009 & 2014 \\
\hline 37 & Diwang International Fortune Center & 303 & Liuzhou & $\begin{array}{l}\text { Guangxi Liuzhou Wang Investment } \\
\text { Group Real Estate Development Co., Ltd. }\end{array}$ & 2011 & 2014 \\
\hline 38 & Greenland Puli Center & 303 & Jinan & Greenland Group & 2010 & 2013 \\
\hline 39 & $\begin{array}{l}\text { Jiangxi Nanchang Greenland Central } \\
\text { Plaza, Parcel A\&B }\end{array}$ & 303 & Nanchang & Greenland Group & 2011 & 2014 \\
\hline
\end{tabular}


TABle 1: Continued.

\begin{tabular}{|c|c|c|c|c|c|c|}
\hline No. & Project name & $\begin{array}{l}\text { Height } \\
(\mathrm{m})\end{array}$ & Location & Client or investor & $\begin{array}{l}\text { Start } \\
\text { time }\end{array}$ & $\begin{array}{c}\text { Completion } \\
\text { time }\end{array}$ \\
\hline 40 & Leatop Plaza & 302.7 & Guangzhou & $\begin{array}{l}\text { Guangdong Leatop Real Estate } \\
\text { Investment Co., Ltd. }\end{array}$ & 2008 & 2011 \\
\hline 41 & Concord International Centre & 301.75 & Chongqing & Success Financial Group & 2009 & 2012 \\
\hline 42 & Anhui New Broadcasting \& TV Center & 301.7 & Hefei & Anhui Broadcasting and TV Station & 2007 & 2012 \\
\hline 43 & Shen Greatwall Financial Center & 300.8 & Shenzhen & $\begin{array}{c}\text { Shenzhen Xiangjiang Real Estate Co., } \\
\text { Ltd. }\end{array}$ & 2008 & 2014 \\
\hline
\end{tabular}

Note. Heights indicate the building tip height.

TABLE 2: Statistics of the skyscraper case study.

\begin{tabular}{|c|c|c|c|c|c|c|c|c|c|c|c|c|c|}
\hline & 1996 & 1997 & 1999 & 2000 & 2006 & 2008 & 2009 & 2010 & 2011 & 2012 & 2013 & 2014 & 2015 \\
\hline Number of projects & 1 & 1 & 1 & 1 & 2 & 1 & 3 & 1 & 5 & 3 & 6 & 16 & 2 \\
\hline Accumulated number of projects & 1 & 2 & 3 & 4 & 6 & 7 & 10 & 11 & 16 & 19 & 25 & 41 & 43 \\
\hline Number of design firms & 5 & 3 & 3 & 2 & 5 & 4 & 6 & 4 & 14 & 5 & 11 & 27 & 7 \\
\hline Accumulated number of design firms & 5 & 8 & 11 & 13 & 17 & 20 & 23 & 27 & 35 & 40 & 45 & 64 & 67 \\
\hline Number of contractors & 3 & 2 & 4 & 1 & 5 & 3 & 8 & 3 & 14 & 6 & 13 & 18 & 6 \\
\hline Accumulated number of contractors & 3 & 5 & 9 & 10 & 14 & 15 & 18 & 22 & 27 & 29 & 34 & 39 & 39 \\
\hline Number of supervisors & 1 & 1 & 1 & 1 & 2 & 1 & 2 & 1 & 5 & 3 & 6 & 16 & 2 \\
\hline Accumulated number of supervisors & 1 & 2 & 3 & 4 & 6 & 7 & 8 & 9 & 11 & 14 & 17 & 25 & 25 \\
\hline
\end{tabular}

Note. (1) The information of the supervisor of Beijing International Trade Centre Building, completed in 2009, is missing. (2) "Cumulative number" consolidates the duplicated organisations.

TABLE 3: Selected SNA measures for the analysis of interorganisational business network.

\begin{tabular}{|c|c|c|c|}
\hline Measures & $\begin{array}{l}\text { Level of } \\
\text { analysis }\end{array}$ & Interpretation and calculations & $\begin{array}{l}\text { Measurement of business network in this } \\
\text { study }\end{array}$ \\
\hline Density & $\begin{array}{l}\text { Whole } \\
\text { networks }\end{array}$ & $\begin{array}{l}\text { Represents the closeness of a network } \\
\text { Calculated by the amount of potential connections } \\
\text { between individuals that are actually present }\end{array}$ & $\begin{array}{c}\text { Relationships of actors, network closeness, } \\
\text { and variation }\end{array}$ \\
\hline $\begin{array}{l}\text { Network } \\
\text { centralisation }\end{array}$ & $\begin{array}{l}\text { Whole } \\
\text { networks }\end{array}$ & $\begin{array}{l}\text { Reflects the extent to which interactions are } \\
\text { concentrated in a small number of individuals rather } \\
\text { than distributed equally among all members } \\
\text { Calculated by the sum of the differences between the } \\
\text { largest individual centrality and all the other individuals } \\
\text { in the network was divided by the maximum possible } \\
\text { sum of differences }\end{array}$ & $\begin{array}{c}\text { Differences between high centrality critical } \\
\text { actors and other actors, and the trends over } \\
\text { time }\end{array}$ \\
\hline $\begin{array}{l}\text { Centralisation } \\
\text { index }\end{array}$ & $\begin{array}{l}\text { Whole } \\
\text { networks }\end{array}$ & $\begin{array}{l}\text { Represents an estimate of the deviation of the largest } \\
\text { values of betweenness centrality computed in the section } \\
\text { nodes, from the value computed for all other nodes } \\
\text { Calculated by dividing the sum of the differences } \\
\text { between the largest individual relative betweenness } \\
\text { centrality and all the other individuals in the network by } \\
(N-1) \text {, where } N \text { represents the number of nodes } \\
\text { Represents the level of importance of a particular node }\end{array}$ & $\begin{array}{c}\text { Differences between high betweenness } \\
\text { centrality critical actors and other actors, and } \\
\text { the trends over time }\end{array}$ \\
\hline Degree centrality & Individual & $\begin{array}{c}\text { in a network } \\
\text { the network }\end{array}$ & $\begin{array}{l}\text { Location of each actor in a business network, } \\
\text { indicating their market position }\end{array}$ \\
\hline $\begin{array}{l}\text { Betweenness } \\
\text { centrality }\end{array}$ & Individual & $\begin{array}{l}\text { Represent the extent to which an actor has control over } \\
\text { information flowing between others } \\
\text { Calculated by the number of times that a node lies along } \\
\text { the shortest path between two other nodes }\end{array}$ & $\begin{array}{c}\text { Location of each actor in a business network, } \\
\text { indicating their ability to control the market } \\
\text { opportunities }\end{array}$ \\
\hline
\end{tabular}

Note. (1) Referring to [34, 40]. 
including designers, contractors, and supervisors, in project $i$ is shown as follows:

$$
C_{\mathrm{LPO}}(i)=\frac{\sum S_{j}^{\prime}}{S_{i}}
$$

where $S_{i}$ represents the total number of designers, contractors, and supervisors in project $i$.

Owners may prefer to collaborate with construction organisations with similar experiences. As a result, in a given year, the theoretical sum of construction organisations in all projects could be greater than the actual number of all participating construction organisations. The larger the gap between two numbers, the more construction organisations are approached by clients for future projects. Thus, the collaboration index $R_{\mathrm{d}}$ is proposed as follows, in order to measure the level of collaborations based on past performance.

$$
R_{d}(n)=\frac{\left(\sum_{i=1}^{n} \sum_{j=1}^{m} S_{i, j}-S_{n}^{\prime}\right)}{S_{n}^{\prime}},
$$

where $n$ represents the year; $m$ represents the number of projects; $S_{i, j}$ represents the number of construction organisations for project $j$ in a given year $i$; and $S_{n}^{\prime}$ represents the real accumulated number of construction organisations until the year $n$. For example, measuring the level of collaboration of all contractors of 10 projects in the past 5 years, $S_{5,6}$ represents the number of contractors of item 6 in the fifth year, and $S_{5}^{\prime}$ represents the real accumulated amount of all contractors in 5 years. In the above formula, $S_{i, j}$ is greater than $S_{n}^{\prime}$, and the higher the $R_{d}$, the greater the difference between the number of theoretical organisations and the actual number in the project. The number of theoretical organisations that can be selected is large, and the number of organisations ultimately selected is small. Very few companies have undertaken most of the projects, resulting in a relatively high degree of project concentration, some companies have a monopoly, and new companies face barriers to entering the market. In this case, a higher $R_{d}$ value means that the owner is more inclined to choose a collaborator with similar project experience. Similarly, the $R_{d}$ can be designed to measure the collaboration level in the selection of designers, contractors, and quality supervisors.

\section{Results}

4.1. Collaboration Based on Past Experience. Collaboration index $R_{\mathrm{d}}$ of different types of organisations from 1996 to 2015 is shown in Figure 2. $R_{\mathrm{d}}$ value of each actor was zero in the first three years, indicating that no repeated collaboration occurred over that period of time. Experienced designers and contractors began to get more opportunities to work in skyscraper projects until the 4th year. Repeated collaborations facilitate the formation of business networks. For suppliers that provided supervision services, repeated collaborations did not occur until the seventh year. On average, the collaboration index that was based on previous experience increased gradually.

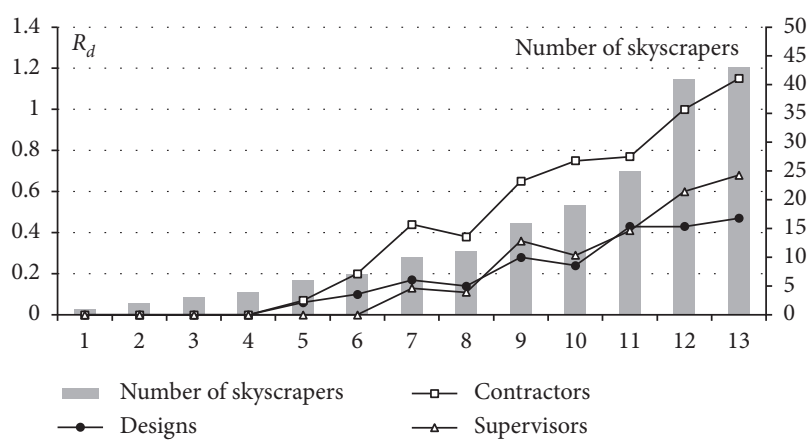

Figure 2: Collaboration index $\left(R_{\mathrm{d}}\right)$ of different types of organisations from 1996 to 2015. The left axis represents the $R_{\mathrm{d}}$ value, which is the value of the line chart; the right axis represents the number of skyscrapers, which is the value of the bar chart. 1-13 on the horizontal axis represents 1996-2015, of which 1998 and 2001-2005 data are missing.

The characteristics of design firms, contractors, and supervisory firms are different despite their overall similar growth trends. Contractors have the highest index, almost twice as high as designers and supervisors. This indicates that experienced contractors have a higher chance to win new projects in the Chinese skyscraper AEC market and contracting segment throws a strict entry barrier to newer entrants, making it more difficult for new contractors to enter the market. On the other hand, designers and supervisors share the similar trend of slow progress, indicating that designers and executives operate in a competitive market and the barriers of entry for newcomers are not as high. For instance, foreign designers constantly participate in design competitions for skyscrapers in China, reflecting the intense competition in this market.

The relationship of the collaboration index $R_{\mathrm{d}}$ and the number of skyscrapers also shows certain correlations. The result of linear regression demonstrates that the collaboration indices and the number of skyscrapers are linearly correlated. The $R^{2}$ values of designer, supervisor, and contractor are $0.8995,0.9113$, and 0.9547 ( $p$ value less than 0.001 ), respectively. Such correlation denotes that companies with similar project experience acquire new project opportunities easier as the number of skyscraper projects under their portfolio increases.

4.2. Interorganisational Business Network. In this study, the Chinese skyscrapers constructed from 1996 to 2015 have been used as data sources to construct the social network model and the results are shown in Figure 3. The points in the figure represent different participants (organisations). The lines represent the collaborative relationship in which each organization establishes a contractual tie with the project. All points are connected by lines to form a simple project network in one project. With the increasing number of projects, the lines interweave with each other, eventually forming a complex social network. Since 1996-2015 involved too many projects and social networks were more complicated, we took 2014 as an example in Figure 3(c), which had the largest number of projects, to construct a 


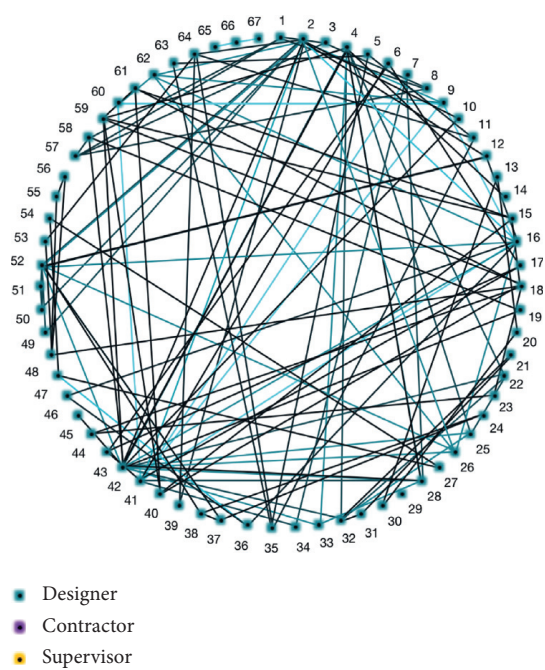

(a)

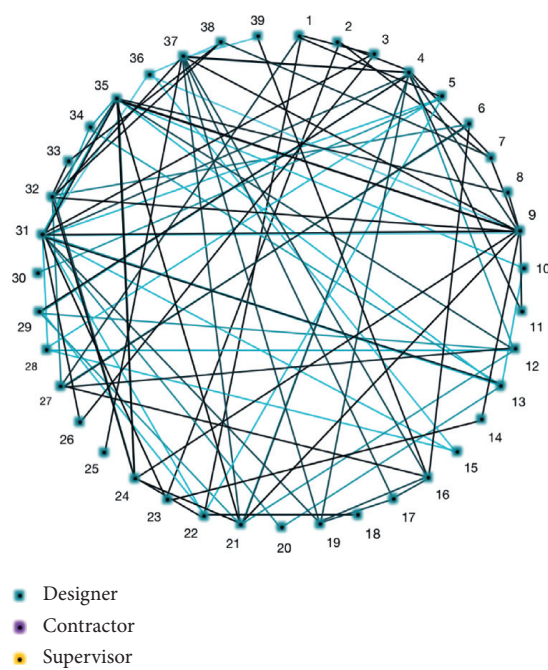

(b)

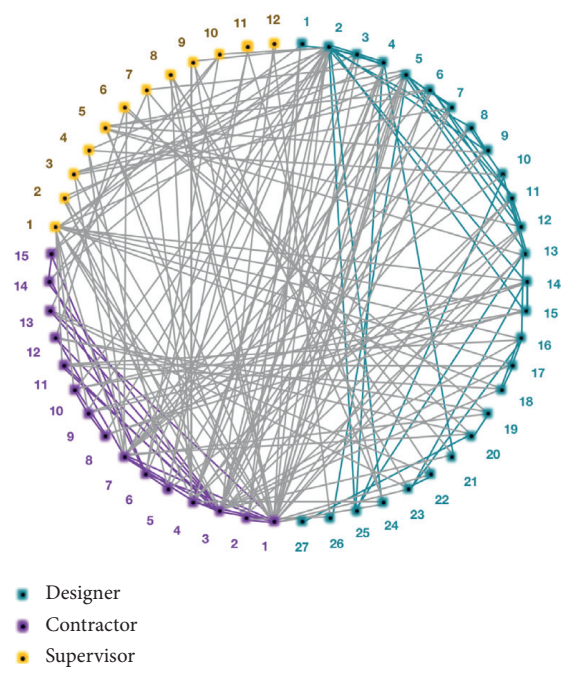

(c)

FIGURE 3: The construction of social network. (a) Map of the business network among designers referred to statistics of the skyscraper cases from 1996 to 2015. The color of the straight line from light to dark indicates the year from early to late. (b) Map of the business network among contractors referred to statistics of the skyscraper cases from 1996 to 2015 . The color of the straight line from light to dark indicates the year from early to late. (c) Map of the business network among designers, contractors, and supervisor referred to statistics of the skyscraper cases in 2004.

business network between designers, contractors, and supervisors.

4.2.1. Analysis of Whole Networks. According to the analysis and integration of Table 3, parameters including density, network centralisation, and centralisation index were used to analyse the formation process, main characteristics, and network evolution within the whole network. Figure 4 illustrates the trends of network centralisation and centralisation index over time. Network centralisation of the whole network reached $7.84 \%$ in the second year and peaked at $11.97 \%$ in the seventh year (year 2009). It stayed at an average of $8.75 \%$ with a standard deviation of 0.0203 despite small fluctuations, showing smaller differences compared to other individuals in the whole network. This result of network centralisation is reasonable when compared to other megaprojects. It is smaller than interorganisational business networks in stand-alone megaprojects, like $23.23 \%$ in the Shanghai Expo construction [41], but larger than in a wider range of metropolises or megacities, such as $6.75 \%$ in a three-year (2008 to 2010) megaproject in a large city in China [42]. On the other hand, the centralisation index reflects the degree of dependence on an intermediate in the whole network. Such an indicator has an overall upward trend with larger fluctuations. The highest value of the centralisation index is $24.05 \%$ in this study, similar to the value in the study of Shanghai Expo (23.59\%) [40]. The most recent value of $18.99 \%$ in this study is slightly higher than the value of $17.18 \%$ in a city-level infrastructure megaproject in China. Due to the high dependence on an intermediate in the network, the network may have "structural holes" that emerge when two separate clusters possess nonredundant information [43]. In Figure 4, the trend of network

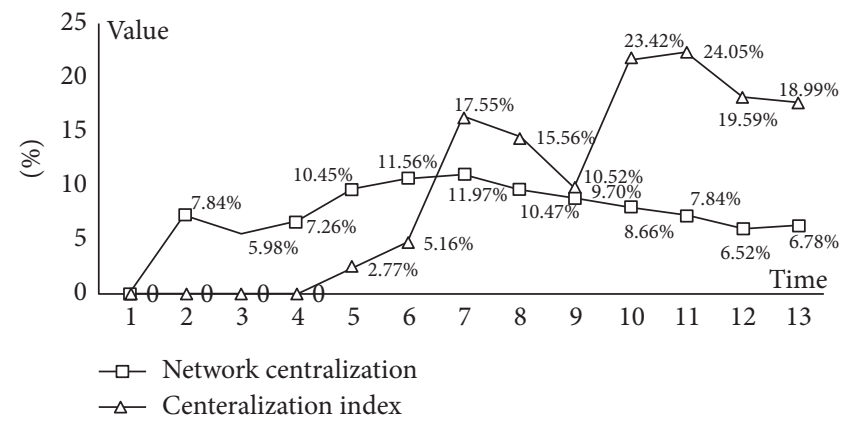

FIGURE 4: Trends of network centralisation and centralisation index of in the skyscraper case study. The $y$-axis represents the value of network centralisation and centralisation index. $1-13$ on the $x$-axis represents 1996-2015, of which 1998 and 2001-2005 data are missing.

centralisation and centralisation index shows a general upward movement with high fluctuations across the timeline. These high fluctuations are manifestations of "structural holes." Thus, a network that bridges structural holes can provide additional value to the network as well as the social capitals in the network.

We further analysed the relationship between the number of skyscrapers and the network centralisation, the centralisation index, and the network density. The results are shown in Figures 4-6. As the number of skyscraper projects increased, so did the network centralisation. However, this only occurred during the first several years, after which it decreased after hitting the highest number in the seventh year (year 2009), showing a polynomial function $\left(R^{2}=0.86\right.$ ) between the two variables (Figure 5). This indicates how complex the evolution of network structures is. In other words, with the increase in this particular type of 


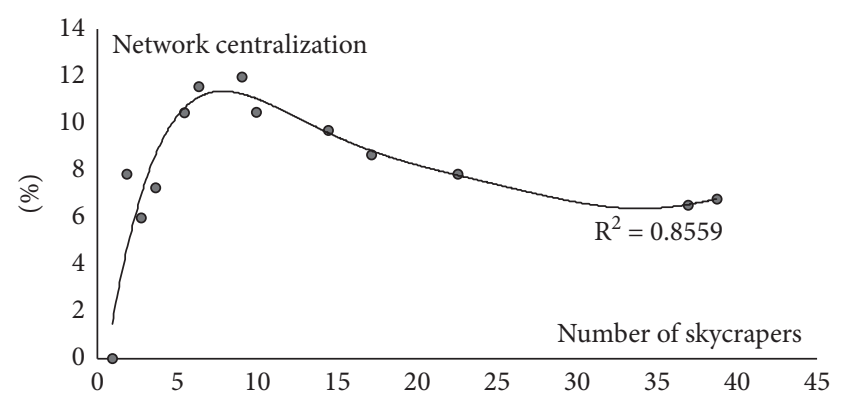

FIGURE 5: The relationship between network centralisation and the number of skyscrapers.

megaprojects and the concentration of business networks, a few key actors can occupy more positions in the business network at the start. However, as the market continues to expand-despite the presence of few key actors-their degree centralities gradually decline. The centralisation index and the number of skyscrapers also correlate with a polynomial function as shown in Figure $6\left(R^{2}=0.88\right)$. The centralisation index dropped after the eleventh year (year 2013), at its peak value of $25 \%$. This indicates that as the number of projects increases, and the project network expands, the betweenness centrality of certain actors increases as well. They control the opportunities in the network and influence the development in the specific megaproject market. In Figure 7, network density and the number of skyscrapers show an exponential relationship $\left(R^{2}=0.96\right)$. The density value reached a stable value of 0.07 as the project number increased. However, the density value of the whole network is lower than the two reference parameters mentioned earlier, 0.3106 in the case of the Shanghai Expo construction and 0.1332 in the case of a megaproject in the China's urban revitalisation $[41,42]$. This may be possible owing to the loose connection between participating organisations and the dispersed geographical locations of skyscrapers in China.

4.2.2. Analysis of Individual in Networks. One of the most important purposes of using social network analysis is to identify the most "important" actors in a network. Some measures attempt to describe and measure properties of their locations in a social network, such as degree centrality, closeness centrality, and betweenness centrality [40]. Compared to whole networks, ego networks include important actors and are generally used for topological analysis; such networks are used to measure parameters such as individual networks and social capital [44]. In this section, we chose two key indicators to measure individual networks, degree centrality, and betweenness centrality to identify and analyse the key actors in a particular skyscraper project business network and how those parameters change over time.

Since there were no repeated organisations in the first four years, Table 4 tabulates the companies of the first-tier degree centrality (top 3 nodes) each year starting from the fiftieth year (year 2006). Design firms and contractors have relatively higher degree centrality. State-owned design firm D2021048 (Shanghai Xian Dai Architectural Design) and

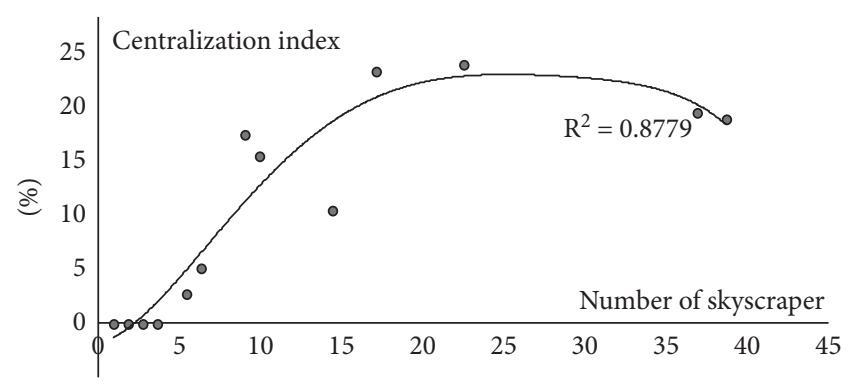

FIgURE 6: The relationship between centralisation index and the number of skyscrapers.

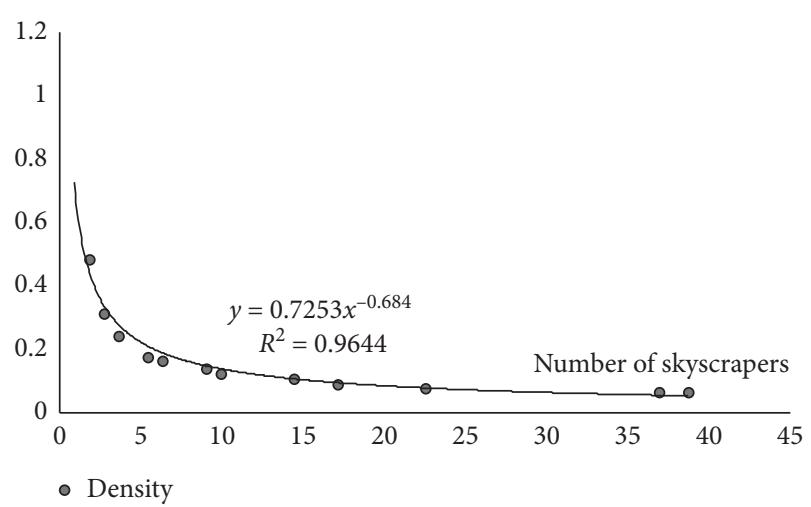

FIgURE 7: The relationship between network density and the number of skyscrapers.

state-owned contractor C3021044 (Shanghai Construction Group) are the top two companies in terms of degree centrality from 2006 till 2013. After 2014, another stateowned contractor C3091077 (China Construction Third Engineering Bureau) and a specialty contractor in curtain walls C4012083 (Jangho Group) gradually moved up in rank in terms of degree centrality (Table 5).

The distribution of degree centrality is rather diversified for different types of construction organisations. Among all designers, D2021048 (Shanghai Xian Dai Architectural Design, SXDAD) ranked the highest in degree centrality. This is followed by two foreign design firms, one specialising in structural design (D2254159, Arup) and another specialising in architectural design (D2254117, SOM). For contractors, C3021044 (Shanghai Construction Group, SCG), C3091077 (China Construction Third Engineering Bureau, CCTEB), and C4012083 (Jangho Group) maintained top positions over the last decade. For all supervisory firms, the distribution of organisations with a higher degree centrality remained relatively stable. S5022047 (Shanghai Project Management Company, SPM) and S5021045 (Shanghai Jianke Project Management Company SJPM) occupied the top two positions since 2009. This indicates that a small number of construction organisations play a significant role in the Chinese skyscraper market and implies that the selections of bids depend largely on the past performance of these construction organisations. Thus, winners took it all and were awarded with most of the projects. 
TABLE 4: Organisations of the first-tier degree centrality (top 3) each year.

\begin{tabular}{|c|c|c|c|c|c|c|c|c|c|}
\hline & 2006 & 2008 & 2009 & 2010 & 2011 & 2012 & 2013 & 2014 & 2015 \\
\hline \multirow{3}{*}{ All organizations } & D2021048 & D2021048 & D2021048 & D2021048 & D2021048 & D2021048 & D2021048 & D2021048 & C3091077 \\
\hline & C3021044 & C3021044 & C3021044 & C3021044 & C3021044 & C3021044 & С3021044 & C3091077 & D2021048 \\
\hline & & C4024138 & D2254117 & D2254117 & D2254117 & D2254117 & D2254117 & C4012083 & C4012083 \\
\hline \multirow{3}{*}{ Design firm } & & & D2 & D20210 & D2021048 & D2021048 & D2021048 & D2021048 & D2021048 \\
\hline & D2021048 & D2021048 & D2254117 & D2254117 & D2254117 & D2254117 & D2254117 & D2254159 & D2254159 \\
\hline & & & & D2254159 & D2254159 & D2254159 & D2254159 & D2254117 & $\mathrm{D} 2254117$ \\
\hline \multirow{3}{*}{ Contractor } & & C3021044 & C3021044 & C3021044 & C3021044 & C3021044 & C3021044 & C3091077 & C3091077 \\
\hline & C3021044 & C4024138 & C4024138 & C4024138 & C4012083 & C4012083 & C4012083 & C4012083 & C4012083 \\
\hline & & & C4021056 & C4021056 & C4052098 & C4052098 & C4052098 & C3021044 & C3021044 \\
\hline \multirow{2}{*}{ Supervisor } & \multirow{2}{*}{-} & \multirow[t]{2}{*}{-} & \multirow{2}{*}{ S5022047 } & \multirow{2}{*}{ S5022047 } & \multirow{2}{*}{ S5022047 } & S5022047 & S5022047 & S5022047 & S5022047 \\
\hline & & & & & & S5031025 & S5021045 & S5021045 & S5021045 \\
\hline
\end{tabular}

Note. (1) The number of organisations in the first tier may be less than three when only one (or two) organization repeatedly occupied the top list. (2) See Table 5 for the company names of the organisations.

TABLE 5: The company names of the organizations in Table 4.

\begin{tabular}{llc}
\hline Type & Code & Name \\
\hline \multirow{2}{*}{ Design firm } & D2021048 & East China Architectural Design \& Research Institute \\
& D2254117 & Skidmore, Owings \& Merrill LLP, SOM \\
& D2254159 & Arup International Consultants (Shanghai) Co., Ltd. \\
\hline \multirow{3}{*}{ Contractor } & C3021044 & Shanghai Construction Group \\
& C 4024138 & Jiatena Curtain Wall Co., Ltd. \\
& C4012083 & China Construction Third Engineering Bureau Co. Ltd \\
Supervisor & C4021056 & Jangho Group Co., Ltd. \\
& S5022047 & Jiangnan Heavy Industry Co., Ltd. \\
& S5031025 & Yuanda China Holdings Limited \\
\hline
\end{tabular}

Table 6 tabulates the first-tier (top 3) organisations of the betweenness centrality from 2006 till 2015. Among all organisations, designers and contractors had a higher betweenness centrality and occupied the key positions in the network, especially D2021048 (SXDAD), C4012083 (Jangho group), and C3091077 (CCTEB). These three organisations ranked first in the network from 2006 to 2011, 2012 to 2014, and 2015, respectively (Table 7).

D2021048 (SXDAD) and D2254159 (Arup) ranked highest on the betweenness centrality among design firms. Although the betweenness centrality of D2254159 (Arup) gradually declined in recent years, it still acted as a key intermediary in the network. After 2013, the betweenness centrality of D2252104 (Dennis Lau \& Ng Chun Man Architects) gradually increased while that of D2254117 (SOM) decreased progressively (it ranked fourth in the year 2015). For contractors, C3021044 (SCG), C3011010 (China Construction Second Engineering Bureau), and C4012083 (Jangho Group), occupied the key position in the network. C3091077 (CCTEB) gradually became a critical intermediary in the network after 2012. For supervisory firms, S5022047 (SPM), S5021045 (SJPM), and S5031025 (Guangzhou Engineering Construction Supervision Company) have been occupying the key position in the network for a maximum of seven years.

According to the social capital theory, social capital is all about the value of connections [44]. The social capital an actor has depends on its position in the network structure. The central proposition is that actors in network positions with higher social capital are likely to have more relationships with new partners in the following time period [30]. If used appropriately, measures such as structural holes, bridges (e.g., betweenness), density, and closeness are indicators to measure social capitals [46]. Based on the metrics from previously analysed cases, it can be seen that the same organisations occupy key positions in skyscraper interorganisational collaboration and business networks. They also controlled the functional location of network structures and had potentially better social capitals. This placed them in a more strategic position to obtain more opportunities. Large state-owned organisations dominated in general contracting, while private organisations had more opportunities in specialty subcontracting. As of 2015, $80 \%$ of the top 20 contractors in degree centrality were owned by the state. On the other hand, foreign companies occupied $60 \%$ of the top 20 design firms, with great reputation, and both US design firm SOM and UK design firm Arup group have good network locations, respectively, in their professional field, architecture design, and construction consultants. The supervision area is almost evenly divided between state-owned and private-owned organisations.

4.2.3. Analysis of Locations in the Networks. We also investigated the trend of locations and its influence on the dynamic network evolution. The average degree centrality 
TABle 6: Organisations of first-tier betweenness centrality (top 3) each year.

\begin{tabular}{|c|c|c|c|c|c|c|c|c|c|}
\hline & 2006 & 2008 & 2009 & 2010 & 2011 & 2012 & 2013 & 2014 & 2015 \\
\hline \multirow{3}{*}{ All organizations } & D2021048 & D2021048 & D2021048 & D2021048 & D2021048 & C4012083 & C4012083 & C4012083 & C3091077 \\
\hline & C3021044 & C3021044 & C3011010 & D2254159 & C4052098 & C3091077 & D2021048 & C3091077 & C4012083 \\
\hline & & C4024138 & D2254117 & D2254117 & D2254159 & D2254159 & C3091077 & D2021048 & D2021048 \\
\hline \multirow{3}{*}{ Design firm } & & & D2021048 & D2021048 & D2021048 & D2254159 & D2021048 & D2021048 & D2021048 \\
\hline & D2021048 & D2021048 & D2254117 & D2254159 & D2254159 & D2021048 & D2252104 & D2254159 & D2254159 \\
\hline & & & & D2254117 & D2254117 & D2254117 & D2254159 & $\mathrm{D} 2252104$ & D2252104 \\
\hline \multirow{3}{*}{ Contractor } & & C3021044 & C3011010 & C3011010 & C4052098 & C4012083 & C4012083 & C4012083 & C3091077 \\
\hline & C3021044 & C4024138 & C3021044 & C3021044 & C3011010 & C3091077 & С3091077 & C3091077 & C4012083 \\
\hline & & & C3011011 & C3011011 & C3021044 & C3021044 & C4052098 & C3011010 & C3021044 \\
\hline \multirow{3}{*}{ Supervisor } & & & & & S5022047 & S5022047 & S5021045 & S5022047 & S5022047 \\
\hline & - & - & S5022047 & S5022047 & S5031025 & S5031025 & S5022047 & S5021045 & S5021045 \\
\hline & & & & & S5021045 & S5021045 & S5031025 & S5031025 & S5031025 \\
\hline
\end{tabular}

Note. (1) The number of organisations in the first tier may be less than three when only one (or two) organization repeatedly occupied the top list. (2) See Table 7 for the company names of the organisations.

TABLE 7: The company names of the organizations in Table 6.

\begin{tabular}{lcc}
\hline Type & Code & Name \\
\hline \multirow{3}{*}{ Design firm } & D2021048 & East China Architectural Design \& Research Institute \\
& D2254117 & Skidmore, Owings \& Merrill LLP, SOM \\
& D2254159 & Arup International Consultants Co., Ltd. \\
& D2252104 & DLN Architects Limited \\
\hline & C3021044 & Shanghai Construction Group \\
Contractor & C4024138 & Jiatena Curtain Wall Co., Ltd. \\
& C3011011 & C3011010 \\
& C3091077 & China Construction First Building (Group) Co., Ltd. \\
& C4052098 & China Construction Second Engineering Bureau Ltd. \\
Supervisor & S5022047 & China Construction Third Engineering Bureau Co. Ltd. \\
& S5031025 & Yuanda China Holdings Limited \\
\hline
\end{tabular}

was used to measure the characteristics of companies-including state-owned companies, private-owned companies, and foreign companies-in the field of design, construction, and supervision, respectively. The results are shown in Figure 8. Private organisations ranked the highest among the three types of companies after 2011, while foreign companies ranked third after 2010. After 2014, the differences among the three types of organisations were minimised (see Figure 8(a)). In the construction market (see Figure $8(\mathrm{~b})$ ), the average degree centrality of private-owned companies increased dramatically and exceeded that of state-owned companies since 2010. From the same year, foreign companies maintained a stable advantage as compared to state-owned companies and private-owned companies in terms of average degree centrality. For designers, three types of companies exhibited a similar decreasing trend in their average degree centrality until 2014 from which they maintained the same level onward (see Figure $8(\mathrm{c})$ ). No foreign company could enter the supervisory market due to administrative regulations. Compared to state-owned companies, the advantage of private companies has gradually been compromised till 2014, in which two types of companies are kept at the same level (see Figure $8(\mathrm{~d})$ ).
In summary, the number of companies does not directly link to the position or power these companies have in a network. Different types of companies-state-owned, private, and foreign-could have diverse characteristics in various fields. Since 2006, private contractors and private designers have gradually started to play a significant role in the network based on their advantages in submarket specialties. However, their market share is still relatively small. State-owned companies occupy key positions in supervising constructions, while foreign companies hold key positions in the field of the design and specialty contracting market.

4.3. The Impact of Locations to Business Network. Figure 9 illustrates the trends for location consistency indicators $C_{\mathrm{LPO}}$ of different company types. The supervisors have had the highest consistency overall. In fact, all supervisory roles for skyscraper projects completed in the first six years (before the year 2008) were undertaken by local supervisors. Designers and contractors were weakly influenced by geographical locations, where the $C_{\text {LPO }}$ stayed 0.2 to 0.3 , indicating that $70 \%$ to $80 \%$ of the organisations were nonlocal. All of these indicate that the impact of interorganisational business networks by geographical locations 


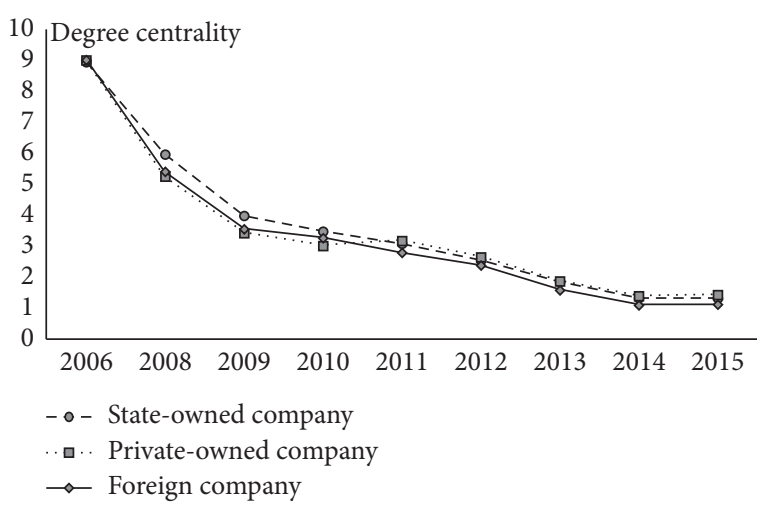

(a)

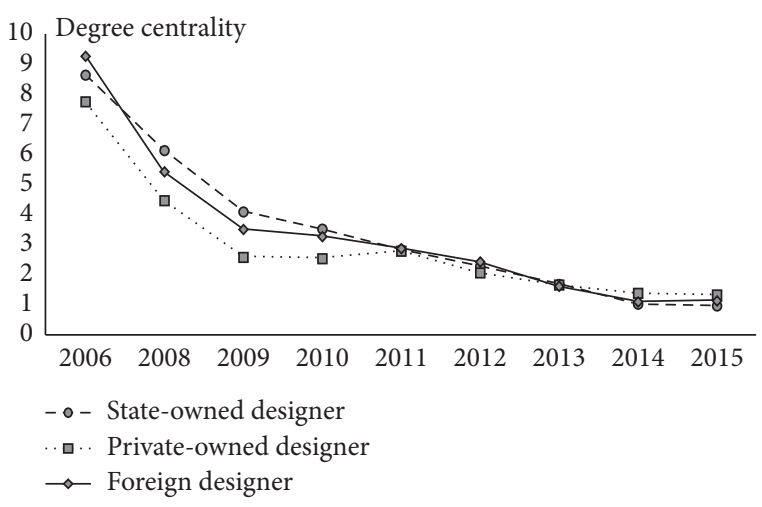

(c)

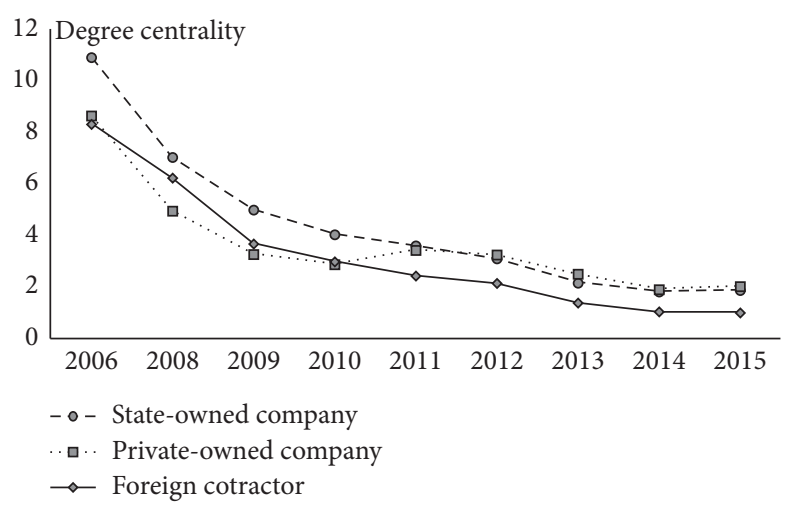

(b)

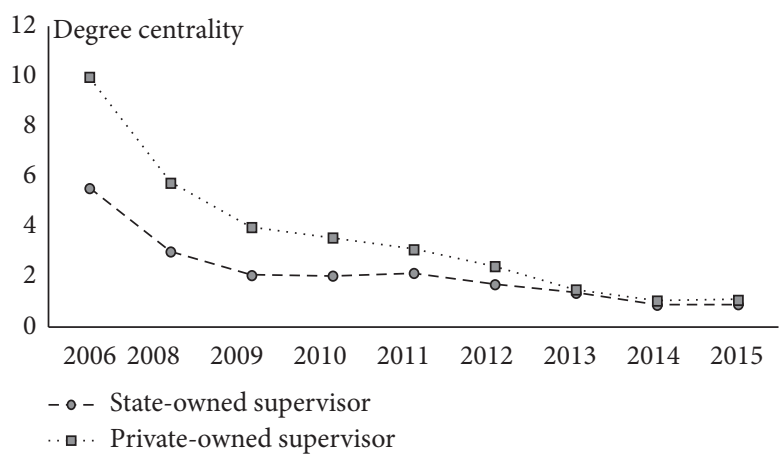

(d)

Figure 8: Trends of average degree centrality of different types of organisations, including (a) all organisations, (b) contractors, (c) designers, and (d) supervisors.

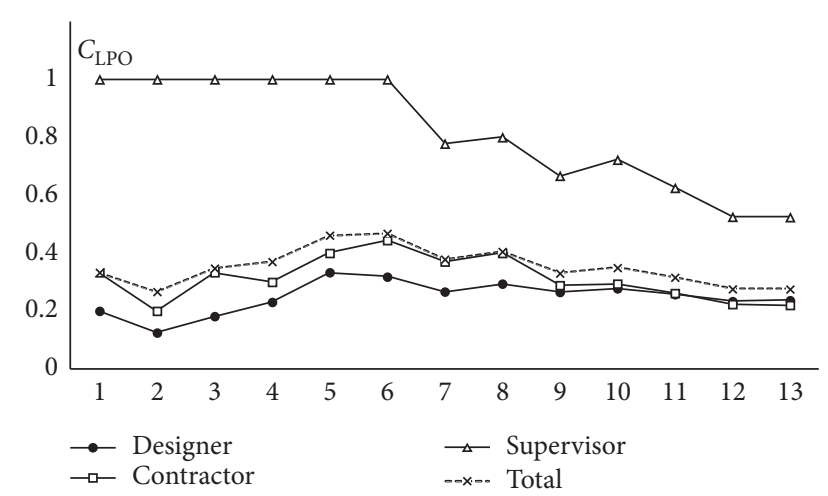

FIGURE 9: The trends of location consistency indicator.

is gradually reducing. This result shows an obvious contrast with the findings that more than $70 \%$ of AEC regular projects in China are built by local or regional organisations. Thus, due to the high complexity and challenge of building skyscrapers, project clients tend to partner with more experienced and established organisations instead of local organisations.

The above finding holds regardless of the type of participants. Figure 10 shows the relationship between the $C_{\mathrm{LPO}}$ of project owners and the $C_{\mathrm{LPO}}$ of other participants. When the $C_{\mathrm{LPO}}$ of project owners increases, both the $C_{\mathrm{LPO}}$ of design firms and the $C_{\mathrm{LPO}}$ of contractors rise accordingly. This implies that the closer a local owner decides to build a project to its headquarters, the higher likelihood that local organisations would be selected. In other words, local owners, compared to foreign owners, tend to select local collaborators.

Further, we analysed the relationship between the location consistency indicator $C_{\mathrm{LPO}}$ and the network centralisation after the second year (Figure 11) to examine the influence of geographical location on the formation of business networks. The result shows that geographical locations correlate positively to the network centralisation $\left(R^{2}=0.5177\right)$, and this is consistent with previous research findings that location organisations enhance the tightness of project collaboration to some extent [15]. However, we did not find obvious correlations between the $C_{\mathrm{LPO}}$ and the centralisation index or between the $C_{\mathrm{LPO}}$ and density.

\section{Discussion and Findings}

In this paper, we implemented SNA and statistical methods to investigate the formation and evolution of interorganisational collaboration and business network based on 43 skyscraper projects that are taller than 300 meters and were built from 1996 to 2015. 187 key participating organisations, including clients, investors, design firms, contractors, subcontractors, and supervisors, were analysed in the dynamic network evolution. We also evaluated the 


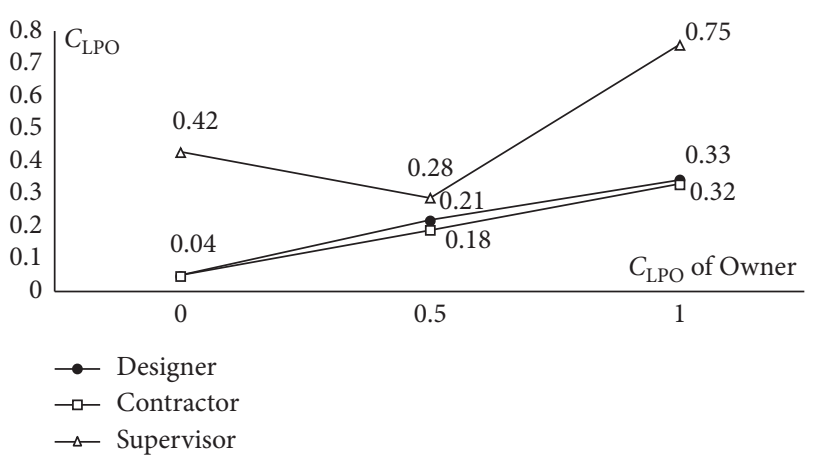

Figure 10: The relationship between $C_{\mathrm{LPO}}$ of owners and $C_{\mathrm{LPO}}$ of other participants.

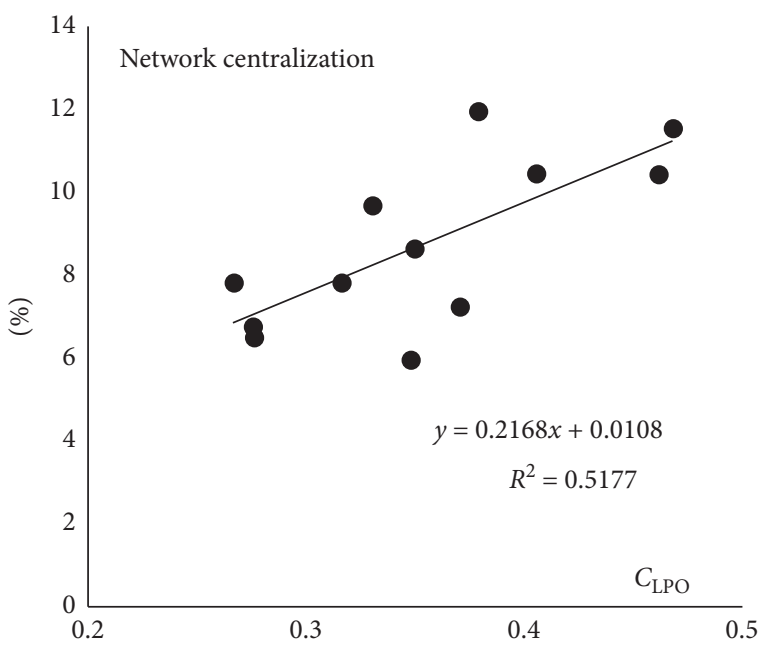

Figure 11: The impact of geographical locations to network centralisation.

influences by organisational types and geographical locations to expand prior research understanding.

5.1. Formation and Evolution of Interorganisational Collaboration and Business Networks. Collaboration between actors results in close work relationships, and this gradually leads to the formation of business networks. Over time, new actors continue to enter the network (such as the number of organisations over time indicated in Table 2). Individual centralisations gradually reduce and the interorganisational relationship tends to stable. Compared to large-scale business networks, this whole network is highly dependent on actors with a high degree of betweenness. The results demonstrated the whole network parameters of business networks in these specific skyscraper megaprojects are in between individual megaproject network and business networks in a more general market. Research on such a specified network could help understand and identify stakeholders' relational behaviours in the AEC project networks, extending the previous exploration of interorganisational network behaviour in the field of megaprojects organization and complementing the previous research on megaproject relational networks [41, 42].
5.2. Positions and Evolutions of Key Actors in the Network. A few actors hold important positions in a megaproject business network. Although their locations change over time, their network locations are relatively stable. This indicates that new project owners tend to choose organisations with experience as partners because they value past experiences. It also reflects that these actors will try to maintain their position in the network, improve network management capabilities, and gain more market opportunities to gain more advantage in the market. This study not only broadens the research areas and themes of "management of a business network," but also supports corporate decision-making, procurement strategy, and network building $[13,14,16]$. We also find that there are a limited number of suppliers that can be selected due to the technical difficulties. There are only a number of 187 major suppliers identified in this study, far less than 6-year regional case studies which have more than 2000 suppliers.

\subsection{Positions and Evolutions of Actors of Different Attributes in} the Network. Megaprojects can be viewed as a complex network of actors, or heterogeneous stakeholders, which include project owners, design firms, and contractors. A lack of prior experience within a megaproject team may further increase the risk of project failure [28, 32, 46, 47]. Key to improving a megaproject's performance lies in constructing an efficient and collaborative team and having an effective organisational network [28, 48]. AEC companies have also had to retain their competitiveness in emerging markets. These companies strive to enhance their market competitiveness by building flagship megaprojects, developing strategic partnerships with other organisations, and increasing their social capital $[12,14,17]$. Therefore, clients, design firms, contractors, and subcontractors may collaborate for short-term project-based performance targets and to achieve long-term market competitiveness $[15,16]$.

\subsection{Influence of Geographical Locations on Owner Procure-} ment, Collaboration, and Business Network Formation and Evolution. For AEC projects, the supply chain, logistics, and procurement strategies are often influenced by geographical locations. Research also demonstrated that the colocations of project partners do not only affect the efficiency of engineering supply chain collaboration [49], but also affect owners in choosing their suppliers [50]. According to Sedita and Apa, actors are able to build a collaborative community, eventually reinforced by colocation over time [15]. However, according to this study, geographical locations are not the major consideration when project owners choose partnering organisations. Although owners may choose partners from a similar geographical location at the start of the project, the influence of such a factor will gradually lessen. From a whole network perspective, local organisations can improve communication and synergies to a certain degree, while geographical locations can influence the network centrality to a certain degree. The more consistent the geographical locations of owners and suppliers are, the higher the network centralisation is. However, we did not find significant 
improvement of local organisations in the network density and betweenness. Therefore, the temporal-spatial impact to the formation and evolution of interorganisational collaboration and business network is complicated.

\section{Conclusions and Limitations}

In this study, we have conducted in-depth research on independent projects or independent organisations and further analysed the formation and evolution of interorganisational collaboration and business networks. In this process, the experience of interorganisational collaboration has a direct impact on network formation, and short-term interorganisational collaboration is the foundation of a long-term interorganisational business network. In the aspect of individual networks, there are key players in the interorganisational business network, and they have different location characteristics in the network. Those organisations become relatively stable in the network as time changes. As a megaproject market develops, geographical location becomes less of a factor when selecting partnerships. However, the project location and the location of team members will impact the centrality of the business network. The spatial and temporal impacts are complex and dynamic. While addressing the limitation in the research area on static networks and stand-alone project networks, we also took into account actor characteristics and long-term temporal-spatial impact within the network. The conclusions and findings shed light on megaproject interorganisational networks and the formation and characteristics of business network.

The conclusions and findings clarify the formation and characteristics of large-scale project interorganisational networks and business networks, provide theoretical applications for contemporary research on project networks and large-scale project management, and provide case studies for the theoretical framework of Artto and Kujala. At the same time, the article integrates multiple aspects of organization, projects, and business networks to improve the influence of interdisciplinary.

In addition to having a thorough understanding of how a business network forms, in terms of practical applications, this article puts forward relevant suggestions for owners to choose suppliers and suppliers to improve market competitiveness. The owner should consider the supplier's past collaboration experience, the characteristics of the collaborators, and the geographic location. Suppliers should adopt different strategies to enter the business network and establish and maintain their own personal network, in order to obtain better network location and market competitiveness.

However, it is important to note that this research is subject to limitations that should be addressed by future studies. We chose skyscrapers as a case example for megaprojects, and only those taller than 300 meters in China were used in the case study; the analysis and results may have changed if we selected a wider range of skyscraper projects, i.e., more than 200 meters, or from different countries. Also, we only studied the core project teams in our research, although building a skyscraper may involve hundreds of organisations working together. The expansion of project teams will most likely affect whole networks and individual networks, and limitations on these grounds provide more opportunities for future research.

In the future, as more megaproject datasets are made available (e.g., high-speed rails, large-scale bridges, and nuclear plants), more in-depth analysis can help us better understand the formation and evolution of megaproject interorganisational business. The further expansion of research categories and their associations to AEC fields and supply chain management can provide a broader perspective on the interorganisational business networks, their dynamic features, and the interactive relationship with external markets. All cases applied in this article use the DBB contract type. Future research should also consider the differences in the formation of business networks under different contract types (such as "design and build" or "EPC"), making the research on business networks more comprehensive. Future research could also link the entire business network to individual cases to further analyse the relationship between the temporal project networks and long-term collaboration networks, and this could further contribute to the theoretical understanding of how project business networks work. The use of interdisciplinary theory and methods is also needed to solve complex network problems, especially in the case of network topology, and the influence of various complex factors of time, space, business attributes, and relationships.

\section{Data Availability}

Part of data used to support the findings of this study are included within Tables 1, 5, and 7. Other data used to support the findings of this study are available from the corresponding author upon request.

\section{Conflicts of Interest}

The authors declare that they have no conflicts of interest.

\section{Acknowledgments}

This study was supported by the Fundamental Research Funds for the Central Universities of China (22120180624), National Natural Science Foundation of China (General Project nos. 52078374 and 71471136), National Social Science Foundation of China under Major Program (17ZDA062), Chinese Academy of Engineering (2020-XZ16), Open Projects Fund of Shanghai Key Laboratory of Urban Renewal and Spatial Optimization Technology (2019010205), Shanghai Municipal Science and Technology Commission (19DZ1202803), Shanghai Municipal Commission of Economy and Informatization Special Fund Programs (Shanghai J-2018-27), and Humanities and Social Sciences of the Ministry of Education of China (16YJC790041). The views represented in this article are those of the individual authors only. 


\section{References}

[1] K. Artto and J. Kujala, "Project business as a research field," International Journal of Managing Projects in Business, vol. 1, no. 4, pp. 469-497, 2008.

[2] J.-Å. Törnroos, A. Halinen, and C. J. Medlin, "Dimensions of space in business network research," Industrial Marketing Management, vol. 61, pp. 10-19, 2017.

[3] B. Flyvbjerg, Introduction: The Iron Law of Megaproject Management, 2017.

[4] G. O. Oliomogbe and N. J. Smith, "Value in megaprojects. Organization, technology \& management in construction," An International Journal, vol. 4, 2012.

[5] H. Håkansson and I. Snehota, "No business is an Island: the network concept of business strategy," Understanding Business Markets, Dryden Press, London, UK, 1989.

[6] E. Gummesson, Total Relationship Marketing, Routledge, Abingdon, U, 2011.

[7] M. Zollo and S. G. Winter, "Deliberate learning and the evolution of dynamic capabilities," Organization Science, vol. 13, no. 3, pp. 339-351, 2002.

[8] M. Zollo, J. J. Reuer, and H. Singh, "Interorganizational routines and performance in strategic alliances," Organization Science, vol. 13, no. 6, pp. 701-713, 2002.

[9] M. Bengtsson and S. Kock, “"Coopetition” in business networks-to cooperate and compete simultaneously," Industrial Marketing Management, vol. 29, no. 5, pp. 411-426, 2000.

[10] A. Halinen and J.- $\AA$. Törnroos, "The role of embeddedness in the evolution of business networks," Scandinavian Journal of Management, vol. 14, no. 3, pp. 187-205, 1998.

[11] B. K. H. Low, "Managing business relationships and positions in industrial networks," Industrial Marketing Management, vol. 26, no. 2, pp. 189-202, 1997.

[12] P. S. Chinowsky, J. Diekmann, and J. O'Brien, “Project organizations as social networks," Journal of Construction Engineering and Management, vol. 136, no. 4, pp. 452-458, 2010.

[13] L. E. Bygballe, M. Jahre, and A. Swärd, "Partnering relationships in construction: a literature review," Journal of Purchasing and Supply Management, vol. 16, no. 4, pp. 239253, 2010.

[14] I. Castro, J. L. Galán, and C. Casanueva, “Antecedents of construction project coalitions: a study of the Spanish construction industry," Construction Management and Economics, vol. 27, no. 9, pp. 809-822, 2009.

[15] S. R. Sedita and R. Apa, "The impact of inter-organizational relationships on contractors' success in winning public procurement projects: the case of the construction industry in the Veneto region," International Journal of Project Management, vol. 33, no. 7, pp. 1548-1562, 2015.

[16] A. Dubois and L.-E. Gadde, "Supply strategy and network effects-purchasing behaviour in the construction industry," European Journal of Purchasing \& Supply Management, vol. 6, no. 3-4, pp. 207-215, 2000.

[17] M. A. Skaates, H. Tikkanen, and K. Alajoutsijärvi, "Social and cultural capital in project marketing service firms: Danish architectural firms on the German market," Scandinavian Journal of Management, vol. 18, no. 4, pp. 589-609, 2002.

[18] A. Jussila, T. Mainela, and S. Nätti, "Formation of strategic networks under high uncertainty of a megaproject," Journal of Business \& Industrial Marketing, vol. 31, no. 5, pp. 575-586, 2016.

[19] S. D. Pryke, "Towards a social network theory of project governance," Construction Management and Economics, vol. 23, no. 9, pp. 927-939, 2005.
[20] G. Winch, "The construction firm and the construction project: a transaction cost approach," Construction Management and Economics, vol. 7, no. 4, pp. 331-345, 1989.

[21] T. P. Hughes, Rescuing Prometheus, Vintage, New York, NY, USA, 2000.

[22] M. Martinsuo and T. Ahola, "Supplier integration in complex delivery projects: comparison between different buyer-supplier relationships," International Journal of Project Management, vol. 28, no. 2, pp. 107-116, 2010.

[23] T. J. Ahola, "Project networks-a short term and a long term view," in Proceedings of the 21st Annual IMP Conference, Rotterdam, Netherlands, 2005.

[24] K. A. Artto and K. Wikström, "What is project business?" International Journal of Project Management, vol. 23, no. 5, pp. 343-353, 2005.

[25] A. Arroyo and D. H. Walker, "Business transformation through an innovative alliance," Procurement Systems-A Cross Industry Project Management Perspective, pp. 423-444, 1999.

[26] P. Davis, Application of Relationship Marketing to Construction, Ph.D. Thesis, Royal Melbourne Institute of Technology, Melbourne, Australia, 2005.

[27] R. A. Owusu, Collective Network Capability in International Project Business Networks-A Case Study of the Business Network for the Ashanti Electrification Project in Ghana, Publications of the Swedish School of Economics and Business Administration, vol. 112, 2003.

[28] I. Ruuska, K. Artto, K. Aaltonen, and P. Lehtonen, "Dimensions of distance in a project network: exploring Olkiluoto 3 nuclear power plant project," International Journal of Project Management, vol. 27, no. 2, pp. 142-153, 2009.

[29] W. Tsai, "Knowledge transfer in intraorganizational networks: effects of network position and absorptive capacity on business unit innovation and performance," Academy of Management Journal, vol. 44, no. 5, pp. 996-1004, 2001.

[30] G. Walker, B. Kogut, and W. Shan, "Social capital, structural holes and the formation of an industry network," Organization Science, vol. 8, no. 2, pp. 109-125, 1997.

[31] B. Flyvbjerg, T. Landman, and S. Schram, Tension Points: Learning to Make Social Science Matter, Critical Policy Studies, Forthcoming, Science Research Network, 2016.

[32] C. Lundrigan, N.A. Gill, and P. Puranam, "The (under) performance of mega-projects: a meta-organizational perspective," Academy of Management Proceedings, vol. 2015, no. 1, p. 11299, 2015

[33] A. Van Marrewijk, S. R. Clegg, T. S. Pitsis, and M. Veenswijk, "Managing public-private megaprojects: paradoxes, complexity, and project design," International Journal of Project Management, vol. 26, no. 6, pp. 591-600, 2008.

[34] Y. Lu, Y. Li, D. Pang, and Y. Zhang, "Organizational network evolution and governance strategies in megaprojects," Construction Economics and Building, vol. 15, no. 3, pp. 19-33, 2015.

[35] C. Haythornthwaite, "Social network analysis: an approach and technique for the study of information exchange," Library \& Information Science Research, vol. 18, no. 4, pp. 323-342, 1996.

[36] M. Loosemore, "Construction crises as periods of social adjustment," Journal of Management in Engineering, vol. 13, no. 4, pp. 30-37, 1997.

[37] L. Zhang and B. Ashuri, "BIM log mining: discovering social networks," Automation in Construction, vol. 91, pp. 31-43, 2018 . 
[38] P. Chinowsky, J. Diekmann, and V. Galotti, "Social network model of construction," Journal of Construction Engineering and Management, vol. 134, no. 10, pp. 804-812, 2008.

[39] S. Pryke, Social Network Analysis in Construction, John Wiley \& Sons, Hoboken, NJ, USA, 2012.

[40] S. Wasserman and K. Faust, Social Network Analysis: Methods and Applications, Cambridge University Press, Cambridge, UK, 1994.

[41] Y. Li, Y. Lu, Y. H. Kwak, Y. Le, and Q. He, "Social network analysis and organizational control in complex projects: construction of EXPO 2010 in China," Engineering Project Organization Journal, vol. 1, no. 4, pp. 223-237, 2011.

[42] Y. Li, Y. Lu, D. Li, and L. Ma, "Metanetwork analysis for project task assignment," Journal of Construction Engineering and Management, vol. 141, no. 12, Article ID 04015044, 2015.

[43] R. S. Burt, Structural Holes: The Social Structure of Competition, Harvard University Press, Cambridge, MA, USA, 2009.

[44] S. Borgatti and P. C. Foster, "The network paradigm in organizational research: a review and typology," Journal of Management, vol. 29, no. 6, pp. 991-1013, 2003.

[45] N. Lin, "Building a network theory of social capital," Connections, vol. 22, no. 1, pp. 28-51, 1999.

[46] B. Flyvbjerg, Megaproject Planning and Management: Essential Readings, Edward Elgar Publishing, Cheltenham, UK, 2014.

[47] S. H. Han, S. Yun, H. Kim, Y. H. Kwak, H. K. Park, and S. H. Lee, "Analyzing schedule delay of mega project: lessons learned from Korea Train express," IEEE Transactions on Engineering Management, vol. 56, no. 2, pp. 243-256, 2009.

[48] P. Chinowsky, J. E. Taylor, and M. Di Marco, "Project network interdependency alignment: new approach to assessing project effectiveness," Journal of Management in Engineering, vol. 27, no. 3, pp. 170-178, 2011.

[49] G. H. Briscoe, A. R. J. Dainty, S. J. Millett, and R. H. Neale, "Client-led strategies for construction supply chain improvement," Construction Management and Economics, vol. 22, no. 2, pp. 193-201, 2004.

[50] W. J. O’Brien, K. London, and R. Vrijhoef, "Construction supply chain modeling: a research review and interdisciplinary research agenda," ICFAI Journal of Operations Management, vol. 3, no. 3, pp. 64-84, 2004. 